\title{
Wine Grape Cultivars Adaptation and Selection for Tropical Regions
}

\author{
U.A. Camargo ${ }^{\text {a }}$ \\ Vino Vitis Consultoria Ltda \\ Bento Gonçalves, RS \\ Brazil
}

\author{
G.E. Pereira ${ }^{b}$ \\ Embrapa Uva e Vinho/ \\ Semi-árido \\ BR $428 \mathrm{Km} \mathrm{152,} \mathrm{CP} 23$ \\ CEP. 56.302-970, Petrolina \\ PE \\ Brazil
}

\author{
C.C. Guerra \\ Embrapa Uva e Vinho \\ Bento Gonçalves, RS \\ Brazil
}

Keywords: tropical viticulture, tropical wine, wine grape evaluation, quality wines, Brazilian viticulture, vineyard management

\begin{abstract}
Wine production is a recent economical activity on tropical regions. In Brazil, tropical wines production started on Sub-Middle São Francisco River Valley Region in the early 1980 years. In the following years, other tropical countries such as Venezuela, Thailand and India have invested in the wine industry. All wine grape cultivars used in the tropical zones are introduced from the traditional temperate winegrowing regions. There are a small number of wine grape cultivars whose cultivation is consolidated in tropical environments, such as 'Syrah' and 'Chenin Blanc', which possess good adaptation and present a great potential of wine quality. Wine grape cultivars evaluation and selection is one of the important priorities in order to diversify the quality wine production in the tropics. The environmental diversity of tropical zones in comparison with the original regions of wine grape cultivars, all of them from temperate climates, requires detailed evaluation and specific cultural practice adjustments to obtain convenient production from each cultivar and for each tropical environment. Climatic factors as winter absence, temperature changes and rain variations throughout the year change the physiological behavior of vines, offering different grapes and wine qualities at different seasons. In this paper are discussed questions inherent to the screening criteria and evaluation methodology to select wine grape cultivars to produce quality wines in tropical regions. Results obtained at the Sub-Middle São Francisco River Valley are presented.
\end{abstract}

\section{INTRODUCTION}

Viticulture is a traditional activity in temperate zones, mainly in the Mediterranean region. The tropical viticulture is a recent activity, however, gaining significance in several regions of hot climate in the world. Some countries like Brazil, Venezuela, India and Thailand, after to develop the table grape industry on tropical environments, started to produce wines in the tropics.

Under tropical conditions the behavior of the grapevine differs considerably from the one observed in temperate regions. The absence of a dormancy period and the use of an appropriate cultivation technology offer the possibility of timing the harvest for any day of the year (Camargo, 2005). This feature brings about the perspective of a great expansion for the tropical viticulture, be it for the continuous market supply with table grapes, or for the possibility to produce large volumes of wine and juice in small industrial plants. The climatic variability found in intertropical zones, due to different altitudes, distribution of rainfalls and temperature variation according to the season of the year have allowed for the identification of regions with a great potential for the production of grapes for fine vintage wines (Tonietto and Carbonneau, 2004; Conceição

\footnotetext{
amberto.camargo@gmail.com; ${ }^{\mathrm{b}}$ gpereira@cpatsa.embrapa.br

Proc. II ${ }^{\text {nd }}$ IS on Tropical Wines

Eds.: G.E. Pereira and J. Tonietto

Acta Hort. 910, ISHS 2011
} 
and Tonietto, 2005; Tonietto et al., 2006). Furthermore, studies on the intra-annual climatic variability in tropical regions suggest that harvest time should be chosen in order to assign priority to wine quality (Tonietto and Teixeira, 2004).

As Vitis vinifera origin is from temperate climate, all of their wine grape cultivars used in the tropics come from the temperate zones. Several cultivars have been essayed in the tropical regions and someone of them as Syrah, Alicante Bouschet, Tempranillo, Chenin Blanc, Muscat Canelli and Colombard have done consistent results in different tropical places, at different tropical countries (Brazil, India, Thailand, Venezuela). However, the wine industry searches for new options to improve the wine quality, to diversify the tropical wines offering different products and developing typical regional wines, according each specific terroir.

In this paper are discussed questions inherent to the screening criteria and evaluation methodology to select wine grape cultivars to produce quality wines in tropical regions. Results obtained at the Sub-Middle São Francisco Valley are presented.

\section{WINE GRAPES IN TROPICAL ENVIRONMENTS}

All of the wine grape cultivars (Vitis vinifera L.) are from the traditional grape growing regions, located in temperate zones and, when cultivated in the tropics, these cultivars require special management techniques to regulate the production to obtain grapes with adequate quality level. On the other hand, grape cultivars have diverse behavior at different tropical places due to climatic variations, resulting of altitude (temperature), length of rainy/dry seasons and cloudiness. Thus, a detailed evaluation of the climatic conditions is the first step to select grape cultivars for a tropical region. The second step is to evaluate what kind of products could be better made at this region. Zones at low altitude normally don't have large day/night temperature variation, resulting in grapes with high sugar levels, low acidity, high $\mathrm{pH}$ and low quality of tannins, anthocyanins and polyphenols. Tropical regions of higher altitudes are preferred for grape growing because the temperatures are milder, which promotes a slow development of vegetation and one longer ripe period of grapes. Mild day temperatures and the occurrence of relatively cold nights favor the accumulation of quality components in red grapes, especially of anthocyanins and tannins, whereas in white ones the aroma intensity and quality are enhanced (Kliever and Torres, 1972; Tonietto and Mandelli, 2003; Mori et al., 2007). Regions with little rainfall throughout the year are apt for production in successive cycles because the risk of disease incidence, especially of mildew (Plasmopara viticola), is low. In regions where the rainy period is concentrated in up to five months it is possible to perform two harvests/year with short-cycle cultivars in the dry season in alternate years, using the system with five cycles three harvests/two years. However, in regions where the rainy season is concentrated in six or more months, it is advisable to carry out two pruning events and one harvest per year, timing the production cycle for the dry period in order to obtain a better grape quality and to reduce the risks (Camargo, 2005). In general, regions at higher altitudes and of which the dry season coincides to the lowest temperatures offer good conditions for quality wines production. According to the climatic conditions, it is possible to infer what type of products could be made in a done region and what cultivar characteristics should be sought for. In the tropics different wine qualities are obtained at the same region because the intra-annual climatic variations. However, at the same season, mainly at the dry season, the climatic conditions are more stable and very similar wine quality can be obtained year after year. Thus, as a quality reference for tropical wines, it seems more important to specify the harvesting season than the year of vintage. 


\section{WINE GRAPE CULTIVARS EVALUATED IN THE SUB-MIDDLE SÃO FRANCISCO VALLEY - BRAZIL}

The Sub-Middle São Francisco Valley region is located in the tropical semi-arid region of Brazil, at latitude $9^{\circ} \mathrm{S}$, longitude $40^{\circ} \mathrm{W}$, at an altitude of $350 \mathrm{~m}$; the climatic average indicators are annual rainfall $500 \mathrm{~mm}$, annual temperature $26^{\circ} \mathrm{C}$ and relative air humidity 50\%. The regional production of wines was developed in the 1980's years, based on the red cultivars Syrah and Alicante Bouschet, and the white cultivars Chenin Blanc and Muscat Canelli. Some years later, the cultivars Cabernet Sauvignon and Ruby Cabernet have also been planted in a commercial scale. More recently cultivar Italia has been processed to make muscat sparkling wines (Asti-type). As a rule, varietal wines are elaborated. In 2002, meeting a demand of the local private wine producers, a research project was launched aiming at the development of technologies for the production of typical quality wines for the region (structured red wines, aromatic white wines, dessert wines, Asti-type sparkling wines). The introduction and selection of cultivars adapted to the local conditions was one of the components of this project. Based on available information, considering the cultivars behavior on the field, must components (acidy, $\mathrm{pH}$, color and flavor) and their wine characteristics, 28 cultivars, including the traditional ones, were pre-selected to be evaluated. The white cultivars selected were Colombard, Flora, Malvasia Bianca, Regner, Siegerrebe, Schönburger, Sylvaner, Viognier and, as reference, Chenin Blanc and Muscat Canelli; the red cultivars were Alfrocheiro, Ancellota, Barbera, Cabernet Sauvignon, Castelão, Deckrot, Grenache, Merlot, Muscat Hambourg, Periquita, Petit Verdot, Ruby Cabernet, Sangiovese, Tempranillo, Tinta Roriz, Trincadeira and, as reference, Syrah and Alicante Bouschet. The essay was established in August 2003, at Fazenda Milano, in Santa Maria da Boa Vista district, in Pernambuco State. Twenty plants of each cultivar were grafted on tropical rootstock IAC 572, which was planted on the field around eight months before. The pergola was used as the training system. The first pruning was carried out in April 2004 and the first harvest was between July and September, according the cycle of each cultivar. The evaluations were made on ten plants each cultivar considering bud burst percentage, phenology, fertility, yield and grape quality ( ${ }^{\circ}$ Brix and total acidity). For some cultivars, data of $\mathrm{pH}$ and content of tartaric and malic acids, anthocyanins and tannins were recorded. Some data concerning to the general behavior of each cultivar, including bud burst easiness, vigor, and pests and diseases occurrence were else recorded. The selection was made intuitively, based on the combination of the field results and, when available, the must analysis and quality of some wines elaborated in very small quantities. The quality attributes for the aimed specific products at the research were considered as priority.

\section{RESULTS AND DISCUSSION}

The data concerning to the field behavior for the 28 cultivars are presented on Table 1. Most of the cultivars showed good fertility potential, standing out Ruby Cabernet, Cabernet Sauvignon, Muscat Hambourg, Regner and Colombard which average fertility was superior to 1,7 bunches per shoot. The cultivars Deckrot, Petit Verdot, Sangiovese, Flora, Siegerrebe and Viognier presented lower fertility than one bunch per shoot. The fertility data aren't directly connected with yield data because the different charge of canes and spurs and even because the differences on the cultivars weight of bunches. Anyway, it is possible to estimate the potential production for each cultivar considering the charge at pruning (canes/spurs), the fertility data and the average of bunch weight. With the exception of Siegerrebe, Schönburger and Ruby Cabernet, all cultivars showed sugar content higher than $20^{\circ}$ Brix at the harvest time. The high acidities, superior to $100 \mathrm{mEq} / \mathrm{L}$, were observed on the cultivars Alfrocheiro, Alicante Bouschet, Barbera, Deckrot, Petit Verdot, Tempranillo, Trincadeira, Chenin Blanc, Flora and Siegerrebe. This last one didn't reach ideal ripe stage because the bunch presented rot incidences. The cycle period, from pruning and harvest, varied between 90 days for cultivar Siegerrebe and 134 days for cultivar Periquita. Some complementary data concerning of must quality were obtained by physical-chemical analysis, which are presented on Table 2 . 
Table 1 shows characteristics of bud burst, yield, must quality and cycle length of 28 wine grape cultivars evaluated in the São Francisco Valley, Brazil.

Table 2 shows the results of physical-chemical analysis of grapes harvested from selected cultivars concerning to the must total acidity, $\mathrm{pH}$, sugar content, total tannins and total anthocyanins, in the São Francisco Valley, Brazil.

The selection of the cultivars was carried out with special emphasis on quality attributes, considering grapes health, sugar and acidity contents and data of must quality recorded as $\mathrm{pH}$, malic acidity, tartaric acidity and, for the red grapes, tannins and anthocyanins concentration. In some cases, because the data lack, the decision was based only on the field records and on the yield data. The production was considered but it was not decisive because, based on the bud burst easiness and fertility data it is possible to estimate and to try to adjust the productivity for each cultivar by management techniques. This adjustment can be easily made at the next stage of research, when the selected cultivars must be evaluated in 0,5 ha plots and the age of plants also can influence low productions. Thus, were selected some cultivars that presented low productivity at the first step of researches but which showed important attributes of quality.

At this first stage of evaluation were selected twelve cultivars, eight red ones and four white ones, of which characteristics are presented following.

\section{Red Grapes}

Alfrocheiro - medium vigor, short internodes, excellent sprout, usually, two shoots per spur, good fertility, small and compact bunches. This cultivar showed enough fertility to increase the yield and it presents high content of anthocyanins, tannins and acidity, important characteristics for warm climates as the Sub-Middle São Francisco Valley. Wines elaborated in the second semester of the year presented, in average, alcohol of $12.5^{\circ} \mathrm{GL}, 8,5$ g. $\mathrm{L}^{-1}$ of total acidity (tartaric acid), $4.2 \mathrm{of} \mathrm{pH,} 3.8$ g. $\mathrm{L}^{-1}$ of total tannins and 385.3 g. $\mathrm{L}^{-1}$ of total anthocyanins. In tasting wines were described with medium color intensity, flavors of tropical fruits, but bitterness. New studies need to be carried out to evaluate other harvest date in influence on phenolic maturation (Pereira et al., 2007a and b).

Barbera - low to medium vigor, only one shoot in most of the spurs, good fertility and production, healthy. Barbera combines good characteristics of production and content of sugar, acidity, anthocyanins and tannins. This is a very promising variety for the tropics. Wines elaborated presented, in average, alcohol of $14.7^{\circ} \mathrm{GL}, 7.6$ g. $\mathrm{L}^{-1}$ of total acidity (tartaric acid), 3.9 of $\mathrm{pH}, 2.7$ g. $\mathrm{L}^{-1}$ of total tannins and $334.8 \mathrm{~g} . \mathrm{L}^{-1}$ of total anthocyanins. In tasting wines were described with high color intensity, flavors of pinus and red fruits and balanced. This cultivar presented an interesting potential to be used in commercial wines.

Castelão - synonym of Periquita in Portugal, however, it seems the cultivars evaluated in this essay under these names are different because here the Castelão cycle is shorter. This cultivar is vigorous, easiness of bud burst, good fertility, high yield and acidity relatively high, short cycle. Wines elaborated presented, in average, alcohol of $12.5^{\circ} \mathrm{GL}, 6.3 \mathrm{~g} . \mathrm{L}^{-1}$ of total acidity (tartaric acid), $4.3 \mathrm{of} \mathrm{pH}, 4.5 \mathrm{~g} . \mathrm{L}^{-1}$ of total tannins and 251.8 g. $\mathrm{L}^{-1}$ of total anthocyanins. In tasting wines were described with little color intensity, flavors of red fruits and balanced.

Deckrot - low vigor shoots with two bunches and low fertility, presenting only one or none bunch. Despite the low production, Deckrot was selected because presented high acidity, intense bluish-purple color of the must and short cycle. This cultivar can be one option to replace cultivar Alicante Bouschet, which is very sensitive to bunch rot diseases, as a source of color for regional wines. In the next essays it is recommended to use higher density and adjust specific nutritional management to get better crops. Wines elaborated presented $11.4^{\circ} \mathrm{GL}$ in alcohol, $4.8 \mathrm{~g} . \mathrm{L}^{-1}$ of total acidity (tartaric acid), 3.9 of $\mathrm{pH}, 3.4 \mathrm{~g} . \mathrm{L}^{-1}$ of total tannins and 714.2 g. $\mathrm{L}^{-1}$ of total anthocyanins. In tasting wines were described with very high color intensity, flavors of vegetal and some black fruits and unbalanced. 
Pinot Noir - This cultivar was introduced as Trincadeira, however, it was identified as Pinot Noir, which is named at Bairrada, Portugal, as Trincadeira da Bairrada. It is different from Trincadeira from the Alentejo, which leaves are clearly more lobed (Catálogo, 1986). At São Francisco Valley it showed low vigor, easiness bud burst; despite the good fertility the yield was low because the small size of bunches. Pinot Noir presents good potential for the region because of high sugar and acidity content. It is necessary to adjust the management practices to improve yield. Higher plantation densities must be tested at next steps of the research. Wines elaborated presented $12.1^{\circ} \mathrm{GL}$ in alcohol, 6.1 g.L. ${ }^{-1}$ of total acidity (tartaric acid), $3.6 \mathrm{of} \mathrm{pH,} 2.1 \mathrm{~g} . \mathrm{L}^{-1}$ of total tannins and 297.2 g.L $\mathrm{L}^{-1}$ of total anthocyanins. In tasting wines were described with litlle color intensity, flavors of red fruits and unbalanced.

Periquita - high vigor, easiness of bud burst, good fertility. This cultivar presents good production, high tannins content, balanced acidity, high levels of tartaric acid and good sugar content; long cycle. Wines elaborated presented $13.4^{\circ} \mathrm{GL}$ in alcohol, 7.6 g. $\mathrm{L}^{-1}$ of total acidity (tartaric acid), 3.9 of pH, 3.5 g.L $\mathrm{L}^{-1}$ of total tannins and 140.9 g.L. ${ }^{-1}$ of total anthocyanins. In tasting wines were described with little color intensity, some vegetal flavors and unbalanced.

Petit Verdot - it showed low vigor, low fertility, very bad bud burst, consequently, low yield. However, Petit Verdot has high must acidity, low $\mathrm{pH}$ and high sugar content. Despite the problems on the field, this cultivar was selected because it presents important quality attributes as the low $\mathrm{pH}$ and the high acidity. Special management techniques should be tested on the next experimental essays to improve yield, as higher plants density, nutritional management and studies to improve bud burst capacity. Wines elaborated presented $13.5^{\circ} \mathrm{GL}$ in alcohol, 8.4 g. $\mathrm{L}^{-1}$ of total acidity (tartaric acid), 3.5 of $\mathrm{pH}, 4.2 \mathrm{~g} . \mathrm{L}^{-1}$ of total tannins and 868.4 g.L $\mathrm{L}^{-1}$ of total anthocyanins. In tasting the wine was described with very high color intensity, flavors of black fruits and cherry, body and balanced. This cultivar is very interesting and can be used to increase tropical wine quality and typicity.

Tempranillo - it presents medium to high vigor, enough bud burst easiness, good fertility and good yield capacity; besides, it presents good acid content and richness of anthocyanins, despite the high $\mathrm{pH}$. Wines elaborated presented $11.9^{\circ} \mathrm{GL}$ in alcohol, 7.6 g. $\mathrm{L}^{-1}$ of total acidity (tartaric acid), $4.0 \mathrm{of} \mathrm{pH}, 4.8 \mathrm{~g} . \mathrm{L}^{-1}$ of total tannins and $262.1 \mathrm{~g} . \mathrm{L}^{-1}$ of total anthocyanins. In tasting this wine was described with medium color intensity, flavors of red and black fruits and balanced. This cultivar was implanted with a great success in the region, having actually about 70 hectares of vineyards.

\section{White Grapes}

Colombard - actually this cultivar isn't the true Colombard, but it was not yet correctly identified. Besides lacking correctly identification, this cultivar was selected because its interesting attributes as medium vigor, easiness budburst, good fertility and production, low $\mathrm{pH}$. This cultivar can be used to produce wines with neutral flavor and low $\mathrm{pH}$ for blends. The wine elaborated presented $11.9^{\circ} \mathrm{GL}$ in alcohol, $9.6 \mathrm{~g} . \mathrm{L}^{-1}$ of total acidity (tartaric acid) and $3.6 \mathrm{of} \mathrm{pH}$. In tasting this wine was described as yellow-tail, acid, fresh, little flavors of white fruits and unbalanced.

Flora - medium vigor, bad bud burst at the basis of branches, specially, where the fertility was lower. This problem comes from the low lateral shoots emission, perhaps because of not enough vigor at the plant formation stage. Flora presents high sugar content, good acidity, high tartaric acid content and low $\mathrm{pH}$. Flora can be a good option to produce dry sparkling wines (Brut) or to produce wines for blend with aromatic wines from Muscat Canelli, Malvasia Bianca, Schönburger and others. Wines elaborated presented $11.7^{\circ} \mathrm{GL}$ in alcohol, $6.4 \mathrm{~g} . \mathrm{L}^{-1}$ of total acidity (tartaric acid) and $3.8 \mathrm{of} \mathrm{pH}$. In tasting this wine was described with yellow-tail, flavored with notes of white fruits and flowers, balanced.

Malvasia Bianca - This is a vigorous cultivar, good spurs bud burst, good fertility, full bunches, high yield, good sugar content, low acidity, fine muscat flavor, sensitive to 
powdery mildew. This cultivar can be a very interesting option to produce sparkling wine Asti type, fine muscat wine and, even, dessert wine. The white wines presented $12.5^{\circ} \mathrm{GL}$ in alcohol, 7.6 g. $\mathrm{L}^{-1}$ of total acidity (tartaric acid) and 3.9 of $\mathrm{pH}$. In tasting this wine was described with yellow-tail, flavors of muscat and white flowers and balanced. This cultivar is very interesting due to its high production.

Schönburger - low vigor, good bud burst, good fertility, loose and small bunches, very small bunches on shoot from spurs, low to medium yield, uniform ripe, very short cycle, balanced sugar and acid content, presents special flavor. Because of low vigor it is advisable to test high plantation density looking for better and balanced production and quality. Schönburger can be a interesting cultivar for São Francisco Valley because it short cycle, that permits to get until three harvests per year, and because its good and intensive flavor. It can be used for white aromatic wines. Wines elaborated presented $8.1^{\circ} \mathrm{GL}$ in alcohol, $5.0 \mathrm{~g} . \mathrm{L}^{-1}$ of total acidity (tartaric acid) and $4.1 \mathrm{of} \mathrm{pH}$. In tasting this wine was described with yellow-tail, flavors of vegetal and some white flowers and unbalanced. This cultivar need to be more studied to evaluate its potential.

Besides the cultivars above, cultivar Muscat Hambourg, a red grape, can be an option to produce rose or white fizzy muscat wines. This cultivar presented very good fertility, high production and good sugar content, but the acidity is low. However, good wines could be elaborated combining Muscat Hambourg, presenting high qualities of aroma, color (rose or blush) and sweetness with some acidity from Colombard, for example.

This research permit to infer on what are the cultivars that present more potential to be cultivated on the São Francisco Valley. The above related cultivars are recommended to be planted in larger plots aiming the evaluation on semi-commercial scale, whatever on the field, at winery and consumers filling on the market.

Besides the varietal wines, in some cases, the results obtained indicate that, probably, blends of wines from different cultivars could contribute decisively to increase the wines quality and, perhaps, to typify the wines of the region.

This research results confirm that the main wine grape cultivars at the present used in São Francisco Valley, as Syrah, Tempranillo, Alicante Bouschet, Ruby Cabernet, Chenin Blanc and Muscat Canelli are among the better adapted to region. However, cultivars Alicante Bouschet and Chenin Blanc are very sensitive to bunch rot diseases, therefore, inappropriate to produce at the rainy season.

Considering the intra-annual climatic variation and the possibility to harvest along the year, it is important to characterize the wines obtained at different seasons from different cultivars, in the first and second semesters. It is also very important to evaluate the ideal ripe stage to harvest each cultivar, according the aimed products (structured red wines, aromatic white wines, dessert wines, Asti-type sparkling wines) according the grape quality components evolution.

\section{Literature Cited}

Camargo, U.A. Grape management techniques in tropical climates. 2005. In: International Congress Viticulture Gesco, 14, 23 a 27/08/2005, Geisenheim, Anais. Geisenheim, Alemanha: Gesellschaft fur Förderung der Forschungsanstalt Geisenheim, p. 251-256.

Camargo, U.A., Amorim, F.M. de., Guerra, C.C. and Lima, M.V.D.O. 2007. Introdução e avaliação de novas cultivares para vinho no Vale do São Francisco. In: Workshop Internacional de Pesquisa: A Produção de Vinhos em Regiòes Tropicais, 1, 17 a 20/08/2004, Recife e Petrolina, PE, Anais. Bento Gonçalves, RS : Embrapa Uva e Vinho. 103-109.

Catálogo das castas de uvas para vinho: Região Demarcada da Bairrada. 1986. [S.1.]: Ministério da Agricultura, Pescas e Alimentação, Instituto de Gestão e Estruturação Fundiária, Divisão de Cadastro Vitivinícola, Não paginado. Projeto de Ampelografia e Sinonímia das Variedadesde videira integrado nas Ações de Pré-adesão”Portugal CEE". 
Conceição, M.A.F. and Tonietto, J. 2005. Climatic potential for wine grape production in the tropical North Region of Minas Gerais State, Brazil. Ver. Bras. Frutic., Jaboticabal, SP. (27):404-407.

Kliever, W.M. and Torres, R.E. 1972. Effect of controlled day and night temperatures on grape coloration. Amer. J. Enol. Viticul. (23)2:71-77.

Mori, K., Goto-Yamamoto, N., Kitayama, M. and Hashizume, K. 2007. Loss of anthocyanins in red-wine grape under high temperature. J. Experimental Botany. 111.(access published april 23, 2007).

Pereira, G.E., Soares, J.M., Guerra, C.C., Alencar, Y.C.L. De, Lira, M.M.P., Lima, M.V.D. de O. and Santos, J. 2007a. Évaluation qualitative de vins blancs produits en climat tropical au Brésil. In: Proceedings of the 59th German Viticulture Congress Wine in motion. 21-25/04/2007a, Stuttgart-Germany.

Pereira, G.E., Soares, J.M., Guerra, C.C., Alencar, Y.C.L. de, Lira, M.M.P., Lima, M.V.D. de O and Santos, J. 2007b. Caractérisation de vins rouges tropicaux produits au Nord-Est du Brésil. In: Proceedings of the 59th German Viticulture Congress Wine in motion. 21-25/04/2007b, Stuttgart-Germany.

Tonietto, J., Mandelli and Clima, F. 2003. In: Uvas Viníferas para Processamento em Regiões de Clima Temperado. Bento Gonçalves: Embrapa Uva e Vinho, (Embrapa Uva e Vinho. Sistema de Produção, 4. Versão eletrônica). Available in: www.cnpuv.embrapa.br/publica/sprod/UvasViniferasRegioesClimaTemperado/clima. htm

Tonietto, J. and Carbonneau, A. 2004. A multicriteria climatic classification system for grape-growing regions worldwide. Agricultural and Forestry Meteorology, Amsterdam. (124):81-97.

Tonietto, J. and Teixeira, A.H. de C. 2004. Climatic zoning of viticultural periods over the year in the tropical zone: application of the methodology of the Geoviticulture MCC System. In: Joint International Conference on Viticultural Zoning, 15 to 19 Nov., Cape Town: South Africa Society for Enology and Viticulture. 76-77.

Tonietto, J., Vianello, R.L. and Regina, M.A. 2006. Caracterização macroclimáticda e potencial enológico de diferentes regiões com vocação vitícola de Minas Gerais. Informe Agropecuário (27) 234:32-55. 
Tables

$\bar{\infty} \quad$ Table 1. Characteristics of bud burst, yield, must quality and cycle length of 28 wine grape cultivars evaluated in the São Francisco Valley, Brazil.

\begin{tabular}{|c|c|c|c|c|c|c|c|c|}
\hline Cultivar & $\begin{array}{c}\text { Number of } \\
\text { Canes }+ \\
\text { Spurs }\end{array}$ & $\begin{array}{c}\text { Number of } \\
\text { Shoots }\end{array}$ & $\begin{array}{r}\text { Number of } \\
\text { Bunches }\end{array}$ & $\begin{array}{c}\text { Fertility per } \\
\text { Shoot }\end{array}$ & $\begin{array}{c}\text { Yield per } \\
\text { Plant } \\
(\mathrm{kg})\end{array}$ & ${ }^{\circ}$ Brix & $\begin{array}{l}\text { Total } \\
\text { acidity } \\
(\mathrm{mEq} / \mathrm{L})\end{array}$ & $\begin{array}{l}\text { Cycle } \\
\text { (days) }\end{array}$ \\
\hline Alfrocheiro & 26,50 & 45,70 & 55,8 & 1,22 & 4,47 & 22,0 & 122 & 113 \\
\hline Alicante Bouschet & 20,25 & 36,25 & 45,5 & 1,26 & 6,91 & 21,0 & 117 & 121 \\
\hline Ancellota & 20,60 & 25,10 & 25,6 & 1,02 & 1,95 & 23,4 & 78 & 127 \\
\hline Barbera & 16,90 & 28,90 & 45,5 & 1,57 & 8,66 & 26,3 & 135 & 126 \\
\hline Cabernet Sauvignon & 21,40 & 32,20 & 59,2 & 1,84 & 5,89 & 22,2 & 84 & 132 \\
\hline Castelão & 24,60 & 45,80 & 66,1 & 1,44 & 13,92 & 19,8 & 99,5 & 103 \\
\hline Deckrot & 19,60 & 33,00 & 27,5 & 0,83 & 1,90 & 19,7 & 190 & 104 \\
\hline Grenache & 24,00 & 42,30 & 59,1 & 1,40 & 11,32 & 22,1 & 85 & 133 \\
\hline Merlot & 19,20 & 26,80 & 34,5 & 1,29 & 4,56 & 20,0 & 61 & 128 \\
\hline Muscat Hambourg & 20,40 & 33,30 & 60,5 & 1,82 & 10,84 & 22,6 & 55 & 133 \\
\hline Periquita & 21,30 & 43,10 & 56,3 & 1,31 & 11,67 & 23,0 & 99 & 134 \\
\hline Petit Verdot & 15,90 & 21,40 & 19,6 & 0,92 & 2,80 & 24,2 & 140 & 132 \\
\hline Syrah & 15,00 & 28,60 & 50,5 & 1,77 & 6,69 & 23,4 & 77 & 132 \\
\hline Ruby Cabernet & 23,80 & 30,90 & 71,4 & 2,31 & 8,84 & 19,6 & 78 & 133 \\
\hline Sangiovese & 18,50 & 26,30 & 22,5 & 0,86 & 4,47 & 21,2 & 80 & 127 \\
\hline Tempranillo & 18,00 & 30,80 & 43,8 & 1,42 & 9,66 & 20,5 & 113 & 113 \\
\hline Tinta Roriz & 20,70 & 35,50 & 55,5 & 1,56 & 11,78 & 21,8 & 76 & 126 \\
\hline Trincadeira & 19,50 & 33,50 & 50,7 & 1,51 & 2,86 & 25,1 & 132 & 118 \\
\hline Chenin Blanc & 19,90 & 37,50 & 45,2 & 1,21 & 6,86 & 24,1 & 105 & 119 \\
\hline Colombard & 19,60 & 36,80 & 64,4 & 1,75 & 15,08 & 20,2 & 86 & 133 \\
\hline Flora & 25,50 & 39,00 & 30,7 & 0,79 & 3,10 & 25,0 & 116 & 110 \\
\hline Malvasia Bianca & 17,70 & 33,60 & 45,1 & 1,34 & 12,57 & 20,0 & 70 & 127 \\
\hline
\end{tabular}


Table 1. (Continued).

\begin{tabular}{|c|c|c|c|c|c|c|c|c|}
\hline Muscat Canelli & 18,40 & 33,90 & 51,3 & 1,51 & 6,97 & 20,9 & 78 & 113 \\
\hline Regner & 20,50 & 27,90 & 51,0 & 1,83 & 5,40 & 21,2 & 75 & 106 \\
\hline Schönburger & 27,78 & 49,88 & 75,5 & 1,51 & 4,64 & 18,9 & 90 & 96 \\
\hline Siegerrebe & 23,10 & 40,00 & 33,6 & 0,84 & 5,37 & 16,1 & 120 & 90 \\
\hline Sylvaner & 24,56 & 42,67 & 70,2 & 1,65 & 9,43 & 21,0 & 60 & 128 \\
\hline Viognier & 18,50 & 31,30 & 30,4 & 0,97 & 3,44 & 20,8 & 65 & 121 \\
\hline
\end{tabular}

Table 2. Results of physical-chemical analysis of grapes harvested from selected cultivars concerning to the must total acidity, $\mathrm{pH}$, sugar content, total tannins and total anthocyanins, in the São Francisco Valley, Brazil.

\begin{tabular}{|c|c|c|c|c|c|c|c|}
\hline Cultivars & $\begin{array}{r}\text { Total acidity } \\
(\mathrm{mEq} / \mathrm{L})\end{array}$ & $\mathrm{pH}$ & $\begin{array}{r}\text { Malic acid } \\
(\mathrm{mg} / \mathrm{L})\end{array}$ & $\begin{array}{c}\text { Tartaric acid } \\
(\mathrm{mg} / \mathrm{L})\end{array}$ & ${ }^{\circ}$ Brix & $\begin{array}{c}\text { Total tannins } \\
(\mathrm{g} / \mathrm{L})\end{array}$ & $\begin{array}{c}\text { Total anthocyanins } \\
(\mathrm{mg} / \mathrm{L})\end{array}$ \\
\hline Alfrocheiro & 111 & 3,78 & 4,9 & 3,7 & 24,0 & 3,1 & 461,7 \\
\hline Barbera & 103 & 3,65 & 8,4 & 3,8 & 25,5 & 2,1 & 394,2 \\
\hline Deckrot & - & - & - & - & - & - & - \\
\hline Castelão & 93 & 3,55 & - & - & 22,0 & 2,9 & 315,0 \\
\hline Periquita & 84 & 3,45 & 2,1 & 6,0 & 20,5 & 3,2 & 187 \\
\hline Petit Verdot & 96 & 3,33 & 5,6 & 2,4 & 24,0 & 1,8 & 208 \\
\hline Tempranillo & 104 & 3,87 & 5,7 & 6,8 & 22,0 & 2,5 & 326 \\
\hline Pinot Noir & - & - & - & - & - & - & - \\
\hline Colombard & 108 & 2,60 & 3,7 & 5,4 & 16,5 & - & - \\
\hline Flora & 90 & 3,10 & 1,0 & 7,9 & 25,0 & - & - \\
\hline Malvasia Bianca & 97 & 3,02 & 3,7 & 3,5 & 19,5 & - & - \\
\hline Schönburguer & 90 & 3,38 & 3,0 & 3,4 & 18,5 & - & - \\
\hline
\end{tabular}


